\title{
Turkish Metalinguistic Awareness Scale: A Validity and Reliability Study
}

\author{
Behice Varışoğlu \\ Department of Turkish and Social Sciences Education, Faculty of Education, Gaziosmanpaşa University, Turkey
}

Copyright $\bigcirc 2018$ by authors, all rights reserved. Authors agree that this article remains permanently open access under the terms of the Creative Commons Attribution License 4.0 International License

\begin{abstract}
The aim of this study is to develop a useful, valid and reliable measurement tool that will help teacher candidates determine their Turkish metalinguistic awareness. During the development of the scale, a pool of items was created by scanning the relevant literature and examining other awareness scales. The materials prepared were re-examined according to the opinions of two lecturers working in the field of Turkish language education and two working in educational science and a draft scale was prepared. The items in the draft scale were evaluated by pre-application, items with a weak measurement relation were removed from the scale and the scale was prepared for factor analysis. The scale, designed as a 5-point Likert type scale, was applied to a total of 480 students. The $\alpha$ value of the scale formulated by factor analysis (Principal Component Analysis) was found to be 0.87 . As a result of the analyses made, it was determined that the scale had 6 sub-factors and factor loadings ranging from 0.499 to 0.841 were found in these factors. These findings show that the scale can be used to determine Turkish metalinguistic awareness and is a valid and reliable measurement tool.
\end{abstract}

Keywords Turkish, Language Awareness, Metalinguistic Awareness, Improving Scale

\section{Introduction}

A nation can maintain its existence by developing a national consciousness and a common language. Language is an important structure which is commonly referred to by the adjective derived from the nation's name and which carries within it all the elements that make up a sense of national identity, enabling the nation to take up a permanent place in history. The elements of national culture are transmitted to and by individuals through language. The nation and the culture to which individuals feel themselves to belong are embodied in language. Furthermore, the ways in which societies think and express themselves also develop and are communicated through language. From this perspective, language can be thought of as one of the deepest bonds connecting one individual to another and to their shared culture. As Aksan [5] points out, language is the element that most strongly reflects the unconscious culture that underpins the relation of people to society.

A nation's conscious development of a common language is also directly related to how that language is used. Using a language is a broad process involving actions practiced by all speakers of the language as much as the individual. As shared patterns of communication and interaction develop through the use of a language, a common language and cultural heritage emerge. Maintaining this heritage also helps to preserve the bond between the past and the future and increases individuals' respect for and loyalty towards their own languages and cultures. The conscious use of a language is the clearest indication of this respect and loyalty.

Language consciousness, language motivation, language awareness and language attitude are important factors affecting language preference and language usage. In this framework, language awareness can be defined as the specific knowledge that an individual has about the language they speak. It can also be described as individual's consciousness and sensitivity towards language teaching, language learning and language usage and as the conscious attention paid to the relationship between culture and language [24]. The fact that an individual is intricately involved with language and culture in a social context enables them to acquire use of language as a natural process. As a result of making language and culture a part of their own lives, all the psychological behaviours, feelings and thoughts individuals develop with regard to language help determine the kinds of language they prefer to use. In this respect, language awareness is also one of the cognitive factors affecting language usage.

Language awareness is an important element that contributes to linguistic unity and promotes consensus and understanding between individuals speaking the same language. If the individual has an awareness of the language they are using, a sense of ownership of the language and sensitivity in using it develops. Language 
awareness consists of the totality of language sensitivity, consciousness and perception. It is general cognition about language. In this respect, language should be assessed as it is, and in its entirety, without being judged, rejected or suppressed.

Metalinguistic awareness means that the individual thinks about the language they are speaking and consciously uses the different structural features that a language provides [18]. It is the totality of the meanings, thoughts, knowledge, and physical aspects that the individual speaks about. It is also a general concept related to many skills that involve basic awareness of language units such as sounds, words, sentences and meaning. When the literature on metalinguistic awareness is examined, it is seen that various sub-topics related to awareness of language sub-dimensions have been investigated, including phonological awareness, morphological awareness, syntactic awareness and semantic awareness. Phonological awareness is the awareness of the relationship between the letters in the alphabet and their vocalization in speech. It approaches words by dividing them into smaller units such as voice, syllable, and rhyme [74]. The type of language awareness most studied in literature is phonological awareness. Morphological awareness is based on having the necessary knowledge about the structure of the words used in the spoken language, for example, distinguishing the roots, prefixes and suffixes of words, declining nouns, and knowing, understanding and being able to use verbs in all their conjugations [47]. The type of awareness that knows how to deploy the structural, functional, and semantic properties of all the elements that make up the sentence is syntactic awareness [18]. Knowing about, comprehending and using rhetorical devices, as well as understanding the content of words and forms such as idioms, phrases and proverbs, is semantic awareness [63]. Beyond these topics, other studies in the literature generally focus on issues such as language awareness, metalinguistic awareness, critical language awareness, cultural awareness and teacher language awareness.

Some of these studies, which reveal the literature in general, are listed below:

Metalinguistic awareness: [60], [68], [45], [40], [19], [26], [12], [44], [2], [77], [62], [7], [43].

Language awareness: [73], [20], [13], [22], [25], [29], [57], [21], [59], [72], [54].

Critical language awareness: [27], [9], [8], [42].

Teacher language awareness: [14], [41], [15], [52].

Phonological awareness: [3], [39], [30], [70], [4], [32], [33], [50], [69], [31], [74], [71], [17], [37], [38], [49], [16], [36], [35], [34], [48], [56], [2], [10], [28], [58], [6], [1].

Morphological awareness: [53], [75].

Syntactic awareness: [63], [11].

Semantic awareness: [76].

Cultural awareness: [55], [67], [64], [24].

\subsection{Importance and Purpose of the Study}

When language awareness is examined in the context of literature, it is seen that issues regarding awareness tend to be handled individually and are mostly focused on certain types of awareness, while other topics are less researched and the sample groups studied mainly consist of children. In all these studies, no specific research has been carried out regarding measurement and evaluation tools for Turkish metalinguistic awareness and the measurement instruments used in the research tend to lag behind the subjects studied.

This study is therefore needed to fill the gap in this area of research, to inspire other researchers to conduct similar research, and to develop a valid, reliable and useful scale for measuring Turkish metalinguistic awareness.

The specific aim of this study was to develop a useful, valid and reliable scale that will help determine the metalinguistic awareness of Turkish teacher candidates.

\section{Method}

\subsection{Study Model}

The research model used in this study is the screening model. It was used in order to provide a suitable model for large sample group surveys [51]. It is a widely used research model and since this is a scale development study based on determining awareness it was suitable for the research.

\subsection{Participants}

In this study, data were collected from 480 teacher candidates studying at Gaziantep University, selected by the easily accessible sampling technique $(\mathrm{N}=78$ for the preliminary application and $\mathrm{N}=402$ for the application). All individuals participated on a voluntary basis.

The descriptive characteristics of the participants are summarized in Table 1:

Table 1. The Characteristics of the Participants

\begin{tabular}{|c|c|c|}
\hline \multicolumn{2}{|c|}{ Characteristics } & N \\
\hline \multirow{3}{*}{ Gender } & Female & 306 \\
\cline { 2 - 3 } & Male & 174 \\
\hline \multirow{4}{*}{ Department } & Turkish Language Education & 218 \\
\cline { 2 - 3 } & Turkish Language and Literature Education & 103 \\
\cline { 2 - 3 } & Classroom Instruction & 97 \\
\cline { 2 - 3 } & Social Sciences Education & 34 \\
\cline { 2 - 3 } & Mathematics Education & 28 \\
\hline \multirow{3}{*}{ Age } & 20 Ages and Under 20 Years of Age & 189 \\
\cline { 2 - 3 } & 21-23 Ages & 173 \\
\cline { 2 - 3 } & 24 Ages and Over 24 & 480 \\
\hline Total & & 118 \\
\hline
\end{tabular}

Tavşancıl [65], who gave recommendations about sample size and how many people should participate, states that the number of participants should be at least 5 times 
higher than the number of items to be analysed with a factor of not less than 100 persons. In this regard, it can be said that the number of participants contributing to the research was sufficient.

\subsection{Study Process}

The process of the study consisted of the following stages: literature survey, item pool creation, validity of scope, pilot study and selection of materials, main implementation for factor analysis, structure validity, reliability calculation, factor analysis, naming and reporting of factor sub-dimensions.

The literature review examined scales developed in the field of language teaching and research on awareness, language consciousness, language use, language awareness, teacher language awareness and pragmatics. Teacher candidates were asked various questions in order to determine the level of their awareness about the topic, and the answers received were found to be inadequate, inconsistent or incomplete. There are many studies on the subject worldwide. In the Turkish literature, however, besides there being only a limited number of studies, it was seen that language awareness is mostly handled in terms of phonetics, morphology, syntax and semantics. It was also observed that studies related to reading and writing language skills are included within this field. It could thus be argued that a comprehensive scale should be developed which includes not only the development of Turkish metalinguistic awareness but also the communicative and cultural dimensions of language.

Based on the studies examined, 15 items were determined for each of the themes of phonological awareness, morphological awareness, syntactic awareness, semantic awareness, communicative awareness and cultural awareness, making a total of 90 items. After the items were identified, they were presented to four experts, two of whom were working in the field of Turkish language education and two in the field of educational science. Items changed following feedback from the experts were rewritten in a form suitable for the 5-point Likert type scale, which would be bi-directional (positive-negative).

The validity of the scope was examined in order to check whether the items in the draft scale to be used in the study were adequate in terms of quantity and quality. Expert opinions were received to determine the validity of scope [23]. Expert opinions were also consulted to determine the intelligibility of the items and whether the characteristics to be measured were reflected in the items in the scale. Some items were corrected according to the feedback from the experts, some were removed from the scale $(\mathrm{n}=26)$ and the final form was then given to the draft scale. After this reorganization, there were 64 items on the draft scale. The scale was pre-applied to 78 students to determine whether the 64 items on the draft scale were appropriate for the sample group and whether they represented the behaviours intended to be measured. According to the data obtained from this process, the Cronbach's alpha $(\alpha)$ value of the draft scale was calculated as 0.79 . After this stage the scale was applied to a sample group of 402 students.

Factor analysis (basic components) was performed to determine the structure validity of the scale. Factor analysis is used for cases in which items in similar categories can be grouped according to similar structures and qualities [46]. Kaiser Meyer Olkin (KMO) and Bartlett's tests, cofactor variance values, eigenvalue, principal component analysis and the varimax rotation technique were used in order to demonstrate the validity of the structure. The reliability of the scale was examined by calculating the Cronbach's Alpha $(\alpha)$ reliability coefficient and item total correlation. The $\alpha$ value is a measure of the internal consistency of the scale and values above 0.70 are considered sufficient for reliability. The item total correlation value is used to explain the correlation between the item score and the total score of the test. The positive values for the item total correlation and its high score indicated that the scale had internal consistency [23].

\section{Findings}

\subsection{Validity of the Structure}

In order to determine whether the data used in the factor analysis were obtained from a suitable sample group, the KMO test was performed. The Barlett test was also performed to show whether the correlation between the factors in the test was adequate [66]. The significance rate of the Bartlett test and a KMO value that is larger than 0.50 are considered to be necessary for the suitability of the sample. The KMO rates are evaluated as follows: 0.60 is moderate; 0.70 is good; 0.80 is very good; 0.90 is excellent [61]. The Barlett test result and the KMO value of this study are presented in Table 2:

Table 2. The Results of KMO and Bartlett test

\begin{tabular}{|c|c|c|}
\hline \multicolumn{3}{|c|}{ KMO and Bartlett Test } \\
\hline \multicolumn{2}{|c|}{ KMO Sufficiency of Sample Measurement } &, 837 \\
\hline \multirow{3}{*}{ Bartlett Test } & $\chi^{2}$ & 3,128 \\
\cline { 2 - 3 } & $\mathrm{df}$ & 820 \\
\cline { 2 - 3 } & $\mathrm{p}<0,05$ &, 000 \\
\hline
\end{tabular}

According to Table 2, the KMO value was 0.837 and the results of the Barlett test were found to be significant. These results showed that the sample size was very good and that the scale items were suitable for factor analysis. Finding a $\mathrm{p}$ value that is smaller than $\mathrm{p}<0.05$ significance level showed that there was a sufficient correlation between the variables to perform factor analysis. 
In order to determine the validity of the structure of the scale, covariance included in the scale were used. The items with a load factor value of 0.45 and above were selected to be included in the process of analysis. According to [23], the value of 0.45 is sufficient at the minimum level. In this study, it was determined that the load factor values of 64 items in the scale ranged from 0.335 to 0.841 . A total of 23 items with a load factor less than 0.500 were removed from the process of analysis and the remaining 41 items were evaluated. The load factor values of the scale consisting of the 41 items remaining are shown in Table 3:

Table 3. The Load Factor Values of the Items of the Scale

\begin{tabular}{|c|c|c|c|c|c|}
\hline Items & Load Factor Values & Items & Load Factor Values & Items & Load Factor Values \\
\hline 1 &, 841 & 15 &, 632 & 29 &, 542 \\
\hline 2 &, 837 & 16 &, 554 & 30 &, 566 \\
\hline 3 &, 815 & 17 &, 728 & 31 &, 503 \\
\hline 4 &, 717 & 18 &, 523 & 32 &, 541 \\
\hline 5 &, 712 & 19 &, 560 & 33 &, 587 \\
\hline 6 &, 675 & 20 &, 552 & 34 &, 544 \\
\hline 7 &, 681 & 21 &, 563 & 35 &, 578 \\
\hline 8 &, 796 & 22 &, 564 & 36 &, 523 \\
\hline 9 &, 549 & 23 &, 543 & 37 &, 582 \\
\hline 10 &, 673 & 24 &, 521 & 38 &, 515 \\
\hline 11 &, 500 & 25 &, 499 & 39 &, 559 \\
\hline 12 &, 538 & 26 &, 575 & 40 &, 532 \\
\hline 13 &, 547 & 27 &, 511 & 41 &, 526 \\
\hline 14 &, 575 & 28 &, 589 & & \\
\hline
\end{tabular}

When the data in Table 3 were examined, the load factor values of 41 items were found to be appropriate. For this reason, analyses were performed to determine the subscales of the scale.

\subsection{Factor Analysis}

An eigenvalue and a line graph are used to show the number of correlations between the items and to determine the number of factors effectively [23]. The line graph obtained for the 41 items is shown in Figure 1:

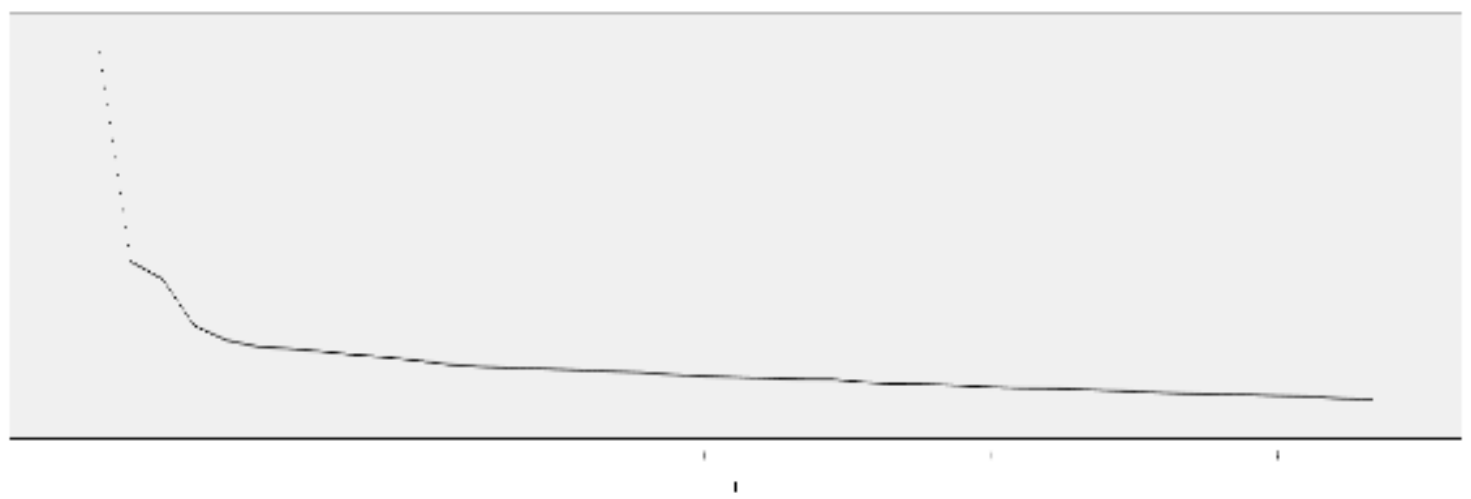

Figure 1. Line Graph Showing the Number of Factor

The line graph obtained by combining the eigenvalues of the items shows the rapid declines that could be seen between the items. The fracture points on the graph were also used to determine the number of factors [23]. In Figure 1, the rapid declines in the line graph start from item 6 and take a horizontal view. According to these values, it can be seen that there were six factors which were more significant and whose eigenvalue was higher than 1 : 
Table 4. Factor Analyses for Eigenvalue of Items of the Scale

\begin{tabular}{|c|c|c|c|c|c|c|}
\hline & \multicolumn{3}{|c|}{ Eigenvalues * } & \multicolumn{3}{|c|}{ Description of Load Factor Frames } \\
\hline Items & Total & Percentage of Variance & Total Percentage & Total & Percentage of Variance & Total Percentage \\
\hline 1 & 2,522 & 6,151 & 29,504 & 2,522 & 6,151 & 29,504 \\
\hline 2 & 1,672 & 4,077 & 30,581 & 1,672 & 4,077 & 30,581 \\
\hline 3 & 1,409 & 3,436 & 37,017 & 1,409 & 3,436 & 37,017 \\
\hline 4 & 1,289 & 3,344 & 47,161 & 1,289 & 3,344 & 47,161 \\
\hline 5 & 1,109 & 3,336 & 64,457 & 1,109 & 3,336 & 64,457 \\
\hline 6 & 1,009 & 3,144 & 70,162 & 1,009 & 3,144 & 70,162 \\
\hline 7 & ,994 & 3,053 & 70,169 & & & \\
\hline 8 & ,991 & 2,935 & 70,212 & & & \\
\hline 9 & ,986 & 2,785 & 70,222 & & & \\
\hline 10 & 985 & 2,678 & 70,309 & & & \\
\hline 11 & ,983 & 2,532 & 70,413 & & & \\
\hline 12 & ,964 & 2,351 & 70,458 & & & \\
\hline 13 & ,924 & 2,254 & 70,507 & & & \\
\hline 14 & 900 & 2,195 & 70,511 & & & \\
\hline 15 & 888 & 2,166 & 70,602 & & & \\
\hline 16 & 863 & 2,105 & 70,621 & & & \\
\hline 17 &, 841 & 2,052 & 70,812 & & & \\
\hline 18 & 821 & 2,002 & 70,956 & & & \\
\hline 19 & ,779 & 1,899 & 71,167 & & & \\
\hline 20 & ,750 & 1,830 & 72,997 & & & \\
\hline 21 & ,731 & 1,783 & 74,780 & & & \\
\hline 22 & ,715 & 1,744 & 76,523 & & & \\
\hline 23 & 697 & 1,699 & 78,222 & & & \\
\hline 24 & 694 & 1,693 & 79,915 & & & \\
\hline 25 & 641 & 1,564 & 81,480 & & & \\
\hline 26 & 610 & 1,489 & 82,968 & & & \\
\hline 27 & 604 & 1,473 & 84,441 & & & \\
\hline 28 & ,584 & 1,424 & 85,865 & & & \\
\hline 29 & ,552 & 1,346 & 87,212 & & & \\
\hline 30 &, 534 & 1,303 & 88,514 & & & \\
\hline 31 & ,529 & 1,290 & 89,804 & & & \\
\hline 32 & ,507 & 1,236 & 91,040 & & & \\
\hline 33 & ,486 & 1,185 & 92,225 & & & \\
\hline 34 & ,460 & 1,121 & 93,346 & & & \\
\hline 35 & ,436 & 1,064 & 94,410 & & & \\
\hline 36 & ,425 & 1,036 & 95,445 & & & \\
\hline 37 & ,417 & 1,018 & 96,463 & & & \\
\hline 38 & ,395 & ,963 & 97,426 & & & \\
\hline 39 & ,383 & ,933 & 98,359 & & & \\
\hline 40 & ,343 & 837 & 99,197 & & & \\
\hline 41 &, 329 & 803 & 100,000 & & & \\
\hline
\end{tabular}

*Basic Component Analysis

The first factor accounted for $6.151 \%$ of the total variance, the second factor accounted for $4.077 \%$ of the total variance, the third factor accounted for $3.436 \%$ of the total variance, the fourth factor accounted for $4.344 \%$ of the total variance, the fifth factor accounted for $3.336 \%$ of the total variance and the sixth factor accounted for $3.144 \%$ of the total variance. 
The cumulative variance for the eigenvalues revealed $70.162 \%$ of the total variance. Tavşanc1l [65] points out that values between $40 \%$ and $60 \%$ indicate that the factor structure is strong. In this case, it was seen that the total variance ratio of the scale developed is sufficient.

The correlation values were examined to determine the distribution of the factors of the scale items. The strongest correlation of variables with which factor was determined by varimax analysis. The factor correlation values of the obtained items are presented in Table 5:

Table 5. Factor Correlation Values of the Items in the Scale

\begin{tabular}{|c|c|c|c|c|c|c|}
\hline \multirow[b]{2}{*}{ Items } & \multicolumn{6}{|c|}{ Factors } \\
\hline & 1 & 2 & 3 & & & \\
\hline 4 & ,624* & & & & & \\
\hline 5 & ,596* & & & & & \\
\hline 12 &, $578^{*}$ & & & & & \\
\hline 11 &, $551 *$ & & & & & \\
\hline 23 &, $545^{*}$ & & & & & \\
\hline 13 & ,514* & & & & & \\
\hline 24 &, $507 *$ & & & & & \\
\hline 20 & & ,662* & & & & \\
\hline 15 & & ,582* & & & & \\
\hline 3 & & ,569* & & & & \\
\hline 21 & & ,496* & & & & \\
\hline 25 & & ,492* & & & & \\
\hline 31 & & ,487* & & & & \\
\hline 35 & & & ,654* & & & \\
\hline 33 & & & ,577* & & & \\
\hline 19 & & & ,504* & & & \\
\hline 26 & & & ,503* & & & \\
\hline 34 & & & ,497* & & & \\
\hline 17 & & & ,474* & & & \\
\hline 14 & & & ,454* & & & \\
\hline 30 & & & & ,605* & & \\
\hline 28 & & & & ,597* & & \\
\hline 2 & & & & ,529* & & \\
\hline 29 & & & & ,485* & & \\
\hline 27 & & & & ,457* & & \\
\hline 9 & & & & ,450* & & \\
\hline 38 & & & & & ,647* & \\
\hline 1 & & & & & ,585* & \\
\hline 37 & & & & & , 468* & \\
\hline 40 & & & & & , 465* & \\
\hline 39 & & & & & ,457* & \\
\hline 41 & & & & & ,455* & \\
\hline 22 & & & & & ,451* & \\
\hline 32 & & & & & & ,687* \\
\hline 7 & & & & & & ,602* \\
\hline 18 & & & & & & ,573* \\
\hline 36 & & & & & & ,548* \\
\hline 16 & & & & & & ,532* \\
\hline 10 & & & & & & ,501* \\
\hline 6 & & & & & & ,481* \\
\hline 8 & & & & & & $469 *$ \\
\hline
\end{tabular}

In Table 5, the factors include items as follows: Factor 1 contains items 4, 5, 12, 11, 23, 13 and 24 . Factor 2 contains items 20, 15, 3, 21, 25 and 31. Factor 3 contains items 35, 33, 19, 26, 34, 17 and 14. Factor 4 contains items 30, 28, 2, 29, 27 and 9. Factor 5 contains items 38, 1, 37, 40, 39, 41 and 22. Factor 6 contains items 32, 7, 18, 36, 16, 10, 6 and 8. The factors were named as follows: phonological awareness, morphological awareness, semantic awareness, syntactic awareness, communicative awareness and cultural awareness. 


\subsection{Reliability Analysis}

As a result of the reliability analysis for 41 items, the Cronbach's alpha reliability coefficient was calculated as 0.87 .

Table 6. Cronbach Alpha Values of the Scale and Sub Factors

\begin{tabular}{|c|c|c|c|c|c|c|c|}
\hline $\begin{array}{c}\text { General Cronbach } \\
\text { Alpha }\end{array}$ & $\begin{array}{c}\text { Number of items } \\
\text { of the scale }\end{array}$ & $\begin{array}{c}\text { Phonological } \\
\text { awareness }\end{array}$ & $\begin{array}{c}\text { Morphological } \\
\text { awareness }\end{array}$ & $\begin{array}{c}\text { Semantic } \\
\text { awareness }\end{array}$ & $\begin{array}{c}\text { Syntactic } \\
\text { awareness }\end{array}$ & $\begin{array}{c}\text { Communicative } \\
\text { awareness }\end{array}$ & $\begin{array}{c}\text { Cultural } \\
\text { awareness }\end{array}$ \\
\hline, 871 & 42 &, 874 &, 869 &, 872 &, 871 &, 876 &, 870 \\
\hline
\end{tabular}

According to Büyüköztürk [23], scales that have a lower limit of reliability coefficients than 0.70 are considered sufficient. In this study, the reliability coefficient, which is determined on the scale, also indicated that there was an expected level of reliability. Other findings for reliability analyses are shown in Table 7.

Table 7. Values Related to Reliability Coefficient of the Scale

\begin{tabular}{|c|c|c|c|}
\hline Items & The average of scale if item deleted & Variance of scale if item deleted & Cronbach Alpha of scale if item deleted \\
\hline VAR00001 & 140,1280 & 499,109 &, 870 \\
\hline VAR00002 & 139,9821 & 488,400 & 868 \\
\hline VAR00003 & 139,7917 & 486,733 & 867 \\
\hline VAR00004 & 139,9345 & 487,661 & 868 \\
\hline VAR00005 & 140,0536 & 484,994 & ,867 \\
\hline VAR00006 & 140,0119 & 489,051 & 868 \\
\hline VAR00007 & 140,3482 & 487,523 & 868 \\
\hline VAR00008 & 140,2560 & 488,687 & 868 \\
\hline VAR00009 & 139,5387 & 493,091 &, 869 \\
\hline VAR00010 & 140,2351 & 491,106 & 869 \\
\hline VAR00011 & 139,8333 & 487,853 & 867 \\
\hline VAR00012 & 139,8155 & 491,375 & 869 \\
\hline VAR00013 & 140,1548 & 491,379 & 869 \\
\hline VAR00014 & 139,8720 & 490,828 & 868 \\
\hline VAR00015 & 140,6994 & 488,163 &, 868 \\
\hline VAR00016 & 140,2470 & 491,649 & 869 \\
\hline VAR00017 & 139,7500 & 491,764 &, 869 \\
\hline VAR00018 & 140,6845 & 488,921 &, 868 \\
\hline VAR00019 & 140,1726 & 495,827 & 870 \\
\hline VAR00020 & 140,2143 & 490,079 &, 868 \\
\hline VAR00021 & 140,1220 & 488,155 &, 868 \\
\hline VAR00022 & 139,9137 & 488,378 & 868 \\
\hline VAR00023 & 140,3214 & 491,538 &, 870 \\
\hline VAR00024 & 140,1488 & 496,945 & 871 \\
\hline VAR00025 & 139,8155 & 491,291 & 869 \\
\hline VAR00026 & 140,2054 & 490,677 &, 869 \\
\hline VAR00027 & 139,9881 & 491,570 & 869 \\
\hline VAR00028 & 139,6548 & 492,418 & 869 \\
\hline VAR00029 & 139,6518 & 493,846 & 869 \\
\hline VAR00030 & 139,5655 & 492,742 & 869 \\
\hline VAR00031 & 139,7351 & 496,004 &, 870 \\
\hline VAR00032 & 139,3988 & 494,575 & 869 \\
\hline VAR00033 & 139,6012 & 492,724 & 869 \\
\hline VAR00034 & 139,8482 & 494,308 & 870 \\
\hline VAR00035 & 139,9970 & 488,660 & 868 \\
\hline VAR00036 & 140,0595 & 488,152 & ,868 \\
\hline VAR00037 & 139,7292 & 490,753 & ,868 \\
\hline VAR00038 & 140,0089 & 488,349 & 868 \\
\hline VAR00039 & 140,3720 & 490,634 &, 869 \\
\hline VAR00040 & 140,0179 & 485,844 & ,868 \\
\hline VAR00041 & 140,0952 & 481,698 & ,866 \\
\hline
\end{tabular}

In order to determine the discrimination between the items on the scale, the difference between the items was examined and the ANOVA test was performed. A significant difference was obtained between the items. The findings are presented in Table 8. 
Table 8. ANOVA Test

\begin{tabular}{|c|c|c|c|c|c|c|}
\hline & & Frame definition & Sd. & Average Frame & F & Sig. $^{*}$ \\
\hline \multirow{2}{*}{ Inter group } & & 1454,792 & 279 & 4,908 & & \\
\hline \multirow{3}{*}{ In-group } & Inter items & 89,620 & 40 & 7,376 & 8,355 & 000 \\
\cline { 2 - 7 } & Increasing & 2650,245 & 2783 &, 871 & & \\
\cline { 2 - 7 } & Total & 2560,893 & 2794 &, 889 & & \\
\hline Total & & 3595,626 & 3047 & 1,362 & & \\
\hline \multirow{2}{*}{$p<0,05$}
\end{tabular}

The Hotelling $\mathrm{t}^{2}$ statistic was used to determine the difficulty level of the scale items. The findings are shown in Table 9:

Table 9. Hotelling $\mathrm{t}^{2}$ Test

\begin{tabular}{|c|c|c|c|c|}
\hline Hotelling $\mathrm{t}^{2}$ & $\mathrm{~F}$ & $\mathrm{df1}$ & $\mathrm{df} 2$ & Sig* $^{*}$ \\
\hline 102,529 & 9,695 & 40 & 256 &, 000 \\
\hline
\end{tabular}

According to the values in Table 9, the findings regarding the discrimination of the items were found to be significant at a significance level of $\mathrm{p}<0.05$.

\section{Result}

This study aimed to develop a scale to determine the Turkish metalinguistic awareness in a sample of teacher candidates. According to the results of the validity and reliability analyses, it was determined that the scale developed was appropriate for determining teacher candidates' metalinguistic awareness. The sub-dimensions of this scale, which has a six-dimensional structure, are as follows:

- phonological awareness,

- morphological awareness,

- semantic awareness,

- syntactic awareness,

- communicative awareness,

- cultural awareness

The general conclusion reached in the study was that the scale is a useful, valid and reliable tool for determining the Turkish metalinguistic awareness of teacher candidates.

\section{Suggestions}

Based on the results of this study, the following suggestions can be made:

1. New measurement tools for each sub-dimension of the scale could be developed.

2. New educational measurement tools could be developed by using research findings from disciplines such as psychology, sociology and linguistics to increase language use, language awareness and language ability.

\section{REFERENCES}

[1] Acarlar, F. (1995). Türkçe kazanımında kullanılan fonolojik süreçlerin incelenmesi ve fonolojik bozukluğu olan çocuklardaki süreçlerle karşılaştırılması. Unpublished doctoral thesis, Ankara: Hacettepe University, the Graduate School of Health Sciences.

[2] Acarlar, F., Ege, P. \& Turan, F. (2002). Development of metalinguistic abilities and its relationship with reading in Turkish children. Turkish Journal of Psychology, 17 (50), 63-73.

[3] Akbey, G. Ö. (2016). Down Sendromlu bireylerin akıcı okuma ve okuduğunu anlama ile fonolojik farkındalık düzeyleri arasındaki ilişki. Unpublished master's thesis, Eskişehir: Anadolu University Institute of Educational Sciences.

[4] Akoğlu, G \& Turan, F. (2012). Eğitsel müdahale yaklaşım1 olarak sesbilgisel farkındalık: zihinsel engelli çocuklarda okuma becerilerine etkileri. Hacettepe University Journal of Education, 42(42), 11-22.

[5] Aksan, D. (2000). Her yönüyle dil, ana çizgileriyle dilbilim, Ankara: TDK Publishing.

[6] Aktan, E. (1996). Çocuğun dil gelişiminde fonolojik duyarlılı̆̆ın (sesbirim duyarlılığı) karş̧laştırılmalı olarak incelenmesi. Unpublished master's thesis, İstanbul: Marmara University, Institute of Social Sciences.

[7] Alderson, J. C. \& Hudson, R. (2012). The metalinguistic knowledge of undergraduate students of English language or linguistics. Language Awareness, 22(4), 320-337.

[8] Ali, S. (2011). Critical language awareness in pedagogic context. English Language Teaching, 4(4), 28-35

[9] Alim, H. S. (2005). Critical language awareness in the US: revisiting issues and revising pedagogies in a resegregated society. Educational Researcher, 34, 24.

[10] [10] Allor, J. H. (2002). The relationships of phonemic awareness and rapid naming to reading development. Learning Disability Quarterly, 25, 47-57.

[11] Altun, M. (2004). A syntactic study on Turkish proverbs. Journal of Academic Studies, 6(21), 79-91.

[12] Andrews, S. (1997). Metalinguistic awareness and teacher explanation. Language Awareness, 6(2), 161-177.

[13] Andrews, S. (2001). The language awareness of the L2 
teacher: its impact upon pedagogical practice. Language Awareness, 10(2\&3), 28-35.

[14] Andrews, S. (2007). "Researching and developing teacher language awareness: developments and future directions", In J. Cummins and C. Davidson (eds.), International Handbook of English Language Teaching, New York: Springer.

[15] Andrews, S. (2008). "Teacher language awareness". In Encyclopaedia of Language and Education, New York: Springer.

[16] Anthony, J.L. \& Francis, J. (2005). Development of phonological awareness. Current Directions in Psychological Science, 14(5), 255-259.

[17] Babayiğit, S. \& Stainthorp, R. (2007). Preliterate phonological awareness and early literacy skills in Turkish. Journal of Research in Reading, 30(4), 394-413.

[18] Batur, Z. \& Beyret, T.N. (2015). Relationship between metalinguistic awareness skills and writing skills of middle school students. Turkish Studies -International Periodical for the Languages, Literature and History of Turkish or Turkic 10(15), 873-892.

[19] Bednar, L. (1990). Enhancing metalinguistic awareness in the literature classroom: two case studies. ERIC Document, ED 320150 .

[20] Belanger, J. (1995). Language awareness surveys: a rationale and three instruments. ERIC Document, ED 379686.

[21] Berry, R. (2014). "Investigating language awareness: the role of terminology." A. Łyda and K. Szczes'niak (eds.), Awareness in Action, Second Language Learning and Teaching, Switzerland: Springer International Publishing.

[22] Bolitho, R., Carter, R., Hughes, R., Ivanic, R., Masuhara, H. \& Tomlinson, B. (2003). Ten questions about language awareness. ELT Journal, 29, 68-72.

[23] Büyüköztürk, Ş. (2007). Sosyal bilimler için very analizi el kitabl $\left(7^{\text {th }}\right.$ edition). Ankara: Pegem Publishing.

[24] Byram, M. (2012). Language awareness and (critical) cultural awareness-relationships, comparisons and contrasts, Language Awareness, 21(1-2), 5-13.

[25] Carter, R. (2003). Language awareness. ELT Journal, 57(1), 123-134.

[26] Cazden, C. B. (1991). Metalinguistic awareness revisited: its contribution to the child's appropriation of form. ERIC Document, ED 362066.

[27] Diniz Leal, M. C. (1998). Critical language awareness in the teaching of Portuguese. Language Awareness, 7(1), 23-34.

[28] Durgunoğlu, A.Y. \& Öney, B. (2002). Phonological awareness in literacy acquisition: it's not only for children. Scientific Studies of Reading, 6(3), 245-266.

[29] Ellis, E. M. (2012). Language awareness and its relevance to TESOL. University of Sydney Papers in TESOL, 7, 1-23.

[30] Emir, C., Girgin, M. C. and Karasu, H. P. (2015). Kaynaştırma ve genel eğitim ögretmenlerinin sesbilgisel farkındalığa ilișkin öğretim etkinliklerini kullanımlarının incelenmesi. Journal of Education and Special Education
Technology, 1(1), 15-33.

[31] Erdoğan, Ö. (2009). The Relationship between the phonological awareness skills and reading skills of the first year students at primary school. Unpublished master's thesis, Ankara: Hacettepe University Social Sciences Institute.

[32] Erdoğan, Ö. (2011). İlk okuma ve yazma süreci için önemli bir beceri: fonolojik farkındalık. Uludăg University Journal of Education Faculty, 24(1), 161-180.

[33] Erkansüel, E. (2011). Ilköğretim 1. sinıf üstün ve normal zeka düzeyindeki öğrencilerin fonolojik farkındalık düzeylerinin okuma başarıları üzerine etkisinin karşılaştırılması. Unpublished master's thesis, İstanbul: İstanbul University Institute of Social Sciences.

[34] Gibbs, S. (2004). Phonological awareness: An investigation into the developmental role of vocabulary and short-term memory. Educational Needs, 5(2), 62-67.

[35] Gillon, G. (2004). Phonological awareness: From research to practice. New York: The Guilford Press.

[36] Gillon, G. (2005). Phonological awareness: Effecting change through the integration of research findings. Language, Speech and Hearing Services in Schools, 36, 346-349.

[37] Gökçe, K. (2006). Ana sinıfina devam eden farkl sosyo-kültürel seviyedeki çocukların fonolojik duyarliliklarının incelenmesi. Unpublished master's thesis, Ankara: Hacettepe University Institute of Social Sciences.

[38] Gül, G. (2006). Hafif derecede zihinsel engelli çocukların okuma becerilerine sesbilgisel farkındalık eğitiminin etkisinin incelenmesi, Unpublished master's thesis, Ankara: Hacettepe University the Graduate School of Health Sciences.

[39] Güldenoğlu, B., Kargın, T. \% Ergül, C. (2016). Sesbilgisel farkındalık becerilerinin okuma ve okuduğunu anlama üzerindeki etkisi: Boylamsal bir çalıșma. İlköğretim Online, 15(1), 251-272.

[40] Hamilton, M.E. and Barton, D. (1980). A word is a word: metalinguistic skills in adults of varying literacy levels. ERIC Document, ED 222859.

[41] Harbon, L. (2007). Short-term international experiences and teacher language awareness. International Education Journal, 8(1), 229-243.

[42] Huang, S. (2013). Revising identities as writers and readers through critical language awareness. English Teaching: Practice and Critique, 12(3), 65-86.

[43] Jackson, D. O. (2014). "Learner Differences in Metalinguistic Awareness: Exploring the Influence of Cognitive Abilities and Language Experience." Ryan T. Miller et al. (eds). In Selected Proceedings of the 2012 Second Language Research Forum, 211-226. Somerville, MA: Cascadilla Proceedings Project.

[44] Jessner, U. (1999). Metalinguistic awareness in multilinguals: cognitive aspects of third language learning. Language Awareness, 8(3\&4), 201-209.

[45] Johns, J. L. (1979). Relationships between metalinguistic awareness and reading achievement. ERIC Document, ED 
136225.

[46] Kalaycı, Ş. (2005). Spss uygulamalı çok değişkenli istatistik teknikleri. Ankara: Asil Publishing.

[47] Karadağ, Ö. \& Kurudayığlu, M. (2010). Türkçedeki kelime türetme özelliğinin ilköğretim öğrencilerinin yazıl1 anlatımlarına yansıması. TÜBAR-XXVII, 437-455.

[48] Karakelle, S. (2004). Fonolojik farkındalik ve harf bilgisinin ilkokuma becerisi üzerindeki etkisi. Istanbul Üniversitesi Psikoloji Çalışmaları Dergisi, 24, 45-56.

[49] Karaman, G. (2006). Ana sinıfina devam eden farkl sosyo-kültürel seviyedeki çocukların fonolojik duyarliliklarının incelenmesi. Unpublished master's thesis, Ankara: Hacettepe University the Graduate School of Health Sciences.

[50] Karaman, G., \&Üstün, E. (2011). Ana sınıfına devam eden çocukların fonolojik duyarlılıklarının bazı değişkenlere göre incelenmesi. Hacettepe University Journal of Education Faculty, 40, 267-278.

[51] Karasar, N. (2009). Bilimsel araştırma yöntemleri $\left(20^{\text {th }}\right.$ edition). Ankara: Nobel Publishing.

[52] Kaya, D. (2010). Exploring teacher language awareness: an example study with prospective English teachers. Unpublished master's thesis, İstanbul: İstanbul University Institute of Social Sciences.

[53] Ke, S. \& Xiao, F. (2015). Cross-linguistic transfer of morphological awareness between Chinese and English. Language Awareness, 24(4), 355-380.

[54] Kissling, E. M. \& O’Donnell, M. E. (2015). Increasing language awareness and self-efficacy of FL students using self-assessment and the ACTFL proficiency guidelines, Language Awareness, 24(4), 283-302.

[55] Littlewood, W. (2001). Cultural awareness and the negotiation of meaning in intercultural communication. Language Awareness, 10(2\&3), 189-199.

[56] Mann, V. A., \& Joy, J. G. (2003). Phonological awareness, speech development and letter knowledge in preschool children. Annals of Dyslexia, 55, 149-173.

[57] Mok, J. (2013). A case study of developing student-teachers' language awareness through online discussion forums. Language Awareness, 22(2), 161-175.

[58] Oktay, A. \& Aktan, E. (2002). A cross-linguistic comparison of phonological awareness and word recognition in Turkish and English. International Journal of Early Years Education, 10(1), 37-48.

[59] Onan, B. \& Özçakmak, H. (2014). Türkçe deyimlerde dil farkındalığı ve işlevsel dil kullanımı. Ana Dili Eğitimi Dergisi, 2(1), 1-22.

[60] Ryan, E. B. (1975). Metalinguistic development and bilingualism. ERIC Document, ED 132842.

[61] Şeker, H., Deniz, S. \&Görgen, İ. (2004). Öğretmen yeterlikleri ölçeği. Milli Eğitim Dergisi, 164, 105-118.
[62] Şen, S., Yıldız, Ç., C. veYılmaz, R. (2010). The Examination of the metalinguistic skills of 5 and 6 - year old children who attend preschool education institutions and who don't. Ondokuz Mayls University Journal of the Faculty of Education, 29(2), 37-54.

[63] Sharwood S., M. (2008). "Morphological and syntactic awareness in foreign/second language learning". In Encyclopedia of Language and Education, Springer.

[64] Shemshadsara, Z. G. (2011). Developing cultural awareness in foreign language teaching. English Language Teaching, 5(3), 95-99.

[65] Tavşanc1l, E. (2002). Tutumların ölçülmesi ve SPSS ile very analizi ( $4^{\text {th }}$ edition). Ankara: Nobel Publishing.

[66] Tezbaşaran, A. A. (1997). Likert tipi ölçek geliştirme kılavuzu. (2th edition). Ankara: Türk Psikologlar Derneği Publishing.

[67] Tomlinson, B. \& Masuhara, H. (2004). Developing cultural awareness. Modern English Teacher, 13(1), 5-11.

[68] Tucker, E. S. (1976). Effects of written language and metalinguistic awareness on language acquisition from 5-12. ERIC Document, ED 137800.

[69] Turan, F. \& Akoğlu, G. (2011). Okul öncesi dönemde ses bilgisel farkındalık eğitimi. Eğitim ve Bilim, 36(3), 153-166.

[70] Turan, F. \& Akoğlu, G. (2014). Okul öncesi dönemde ev okuryazarlı ortamı ve fonolojik farkındalı becerileri. Hacettepe University Journal of Education Faculty, 29(3), 153-166.

[71] Turan, F. \& Gül, G. (2008). Early precursor of reading: acquisition of phonological awareness skills. Educational Sciences: Theory and Practice, 8(1), 265-284.

[72] White, J. \& Kennedy, S. (2014). Language awareness: a world of perspectives, Language Awareness, 23(1-2), 1-2.

[73] Wright, M. \& Bolitho, R. (1993). Language awareness: a missing link in language teacher education. ELT Journal, 47(4), 292-304.

[74] Yücel, D. (2009). Sesbilgisel farkındalık (fonolojik farkındalı) eğitiminin okuma sorunu olan çocuklar üzerindeki etkisinin incelenmesi. Unpublished master's thesis, Ankara: Hacettepe University the Graduate School of Health Sciences.

[75] Zhang, Y. \& Li, R. (2016). The role of morphological awareness in the incidental learning of Chinese characters among CSL learners, Language Awareness, 25(3), 179-196.

[76] Zheng, Y. (2014). The fluctuating development of cross-linguistic semantic awareness: a longitudinal multiple-case study, Language Awareness, 23(4), 369-388.

[77] Zipke, M. (2008). Teaching metalinguistic awareness and reading comprehension with riddles. Reading Teacher, 62(2), 128-137. 